\title{
Physico-chemical properties of the African pear and Black olive from different agro-ecological zones of Cameroon
}

Florence A. FonTEH ${ }^{*}$, Tatanja A. NIBA, Joseph TCHOUMBOUE

Department of Animal

Production,

Faculty of Agriculture, University of Dschang, PO Box 447, Dschang,

Cameroon

fontehflorence@yahoo.com

${ }^{*}$ Correspondence and reprints

Fruits, 2005, vol. 60, p. 107-113 (C) 2005 Cirad/EDP Sciences All rights reserved

DOI: 10.1051/fruits:2005021

RESUMEN ESPAÑOL, p. 113

\section{Physico-chemical properties of the African pear and Black olive from different agro-ecological zones of Cameroon.}

Abstract - Introduction. Dacryodes edulis and Canarium schweinfurthii are two tropical multi-purpose trees in Cameroon which produce fruits (African pear and Black olive, respectively) for human consumption, which are marketed more and more on the national and international markets. This study aimed at characterising these two fruits starting from their physical and chemical properties. Materials and methods. Fruits were collected during the harvest peak in three agro-ecological zones of Cameroon. The physical properties measured were the weight, the length, the fruit circumference and the pulp thickness, while the chemical analyses included the moisture and protein, lipid and ash contents. Results. The fruits from the humid forest were largest $(96 \mathrm{~g})$, whereas the smallest came from the grassland (54 g). The highest pulp per fruit content (69\% for the African pear and 57\% for Black olive) was observed in fruits harvested in the humid forest zone. The strongest correlation $(r=0.25)$ between the fruit weight and that of pulp was observed for Black olive produced in the humid forest zone. The crude protein rate was highest (8\%) in fruits from the humid forest, whereas that of the lipids (42\%) prevailed in the semi-forest zone. Conclusion. The humid forest zone offers the best agro-ecological conditions for commercial production of the fruits of D. edulis and C schweinfurthii. These two fruits contain proteins and lipids in significant quantities and can, consequently, be used as alternative sources for these nutritive elements.

Cameroon / multiple-use trees / Dacryodes edulis / Canarium schweinfurtbii / fruits / proximate composition

Propriétés physico-chimiques du safou et de l' "olive noire " produits dans différentes zones agro-écologiques du Cameroun.

Résumé - Introduction. Dacryodes edulis et Canarium schweinfurthii sont deux arbres tropicaux à usages multiples au Cameroun qui produisent, pour la consommation humaine, des fruits (le safou et l'olive noire, respectivement) qui sont de plus en plus commercialisés sur les marchés nationaux et internationaux. Cette étude a cherché à caractériser ces deux fruits à partir de leurs propriétés physiques et chimiques. Matériel et méthodes. Les fruits ont été collectés en pleine saison de récoltes dans trois zones agro-écologiques du Cameroun. Les propriétés physiques mesurées ont été le poids, la longueur, la circonférence du fruit et l'épaisseur de la pulpe, tandis que les analyses chimiques ont porté sur les taux d'humidité, de protéines, lipides et cendres. Résultats. Les fruits provenant de forêt humide ont été les plus gros $(96 \mathrm{~g})$ alors que les plus petits provenaient de la savane $(54 \mathrm{~g})$. Le rendement de la pulpe du fruit le plus élevé (69\% pour le safou et $57 \%$ pour l'olive noire) ont été enregistré dans les fruits récoltés en forêt humide. La plus forte corrélation $(r=0,25)$ entre le poids du fruit et celui de la pulpe a été observée pour l'olive noire produite en zone forestière humide. Le taux de protéine brute a été le plus élevé ( $8 \%$ ) dans les fruits de forêt humide alors que celui des lipides ( $42 \%$ ) a prédominé en zone semi-forestière. Conclusion. La zone de forêt humide offre de meilleures conditions agro-écologiques pour une production commerciale des fruits de D. edulis et C. schweinfurthii. Ces deux fruits contiennent des protéines et des lipides en quantités significatives et peuvent, par conséquent, servir de sources auxiliaires pour ces éléments nutritifs.

Cameroun / arbre à usages multiples / Dacryodes edulis / Canarium schweinfurtbii / fruits / composition globale 


\section{Introduction}

The African pear tree Dacryodes edulis (H.J. Lam) and the Black olive tree Canarium schweinfurthii (Engl.) are two tropical oleiferous fruit trees [1]. They both belong to the Burseraceae family and, as multipurpose trees, they possess enormous potential in Africa. Their fruits are popular in the diets of many Africans [2, 3], and the seed can be incorporated into animal feed [4]; various parts of the trees are used in traditional medicine [2, 4]; the wood serves for firewood, timber and carpentry [3], while the entire tree is used in agro-forestry systems for soil conservation, fertility, shade [5] and in apiculture [2], etc. They grow in a wide variety of climate and soil types and are widely distributed in Africa ranging from Nigeria in the west to Uganda in the east, passing through Cameroon, Equatorial Guinea, Gabon, Congo, Democratic Republic of Congo and down to Angola [6, 7]. In Cameroon, D. edulis and C. schweinfurthii are found throughout the southern part of the country, which comprises different agro-ecological zones [8, 9]. Production and nutrient content of these fruits are expected to vary between different agro-ecological zones [1].

The African pear is consumed both at the village and city levels and is exported to neighbouring countries as well as to Europe. Because of its high lipid content, the oil is reportedly extracted traditionally from the pulp and sold as cooking oil [10]. This indicates that the fruit makes a major contribution towards income generation for the rural populace. Therefore, a better appreciation of its nutritive value is worthy of study.

Very little scientific work has been done in Cameroon on either the physiology of the African pear tree $[1,11]$ or on the physicochemical properties of its fruits [12]. Worse still, no information is available in the literature as regards the physico-chemical properties of the Black olive grown in Cameroon.

Therefore, the objectives of this study were to evaluate some of the physical and chemical properties of the African pear and the Black olive from different agro-ecological zones in Cameroon.

\section{Materials and methods}

\subsection{Collection sites}

Three agro-ecological zones in Cameroon where the African pear and Black olives are predominantly produced were chosen for our study: the humid forest zone, the semihumid forest zone and the grassland zone. One production area was identified for each zone for the collection of fruits. These areas were chosen based on the volume of fruits sold in their markets during the harvest season. Consequently, the collection sites selected were Kekem, Makenene and Dschang, each one being characteristic of one of the three agro-ecological zones determined (table I).

\subsection{Collection of fruits}

The fruits were bought from the markets of the various collection sites during the peak harvest season (July/August for the African pear and November/December for the Black olive). For analyses, 20 African pears and 25 Black olives were collected at random and used. Collection was repeated three times and a fortnight's interval was respected between each collection.

Each fruit was prepared by washing it with distilled water, then dried with a clean cloth and weighed. The length and circumference of each fruit was recorded. A knife was used to cut through the pulp and the thickness was also recorded. Then a hand grater was used to grate and carefully separate the pulp from the seed. The weight of each fruit pulp was separately recorded. After that, all the pulps from each fruit type were bulked together and mixed properly by hand to ensure homogeneity of the mass before samples were withdrawn for chemical analysis. Percentage pulp yield was calculated as: [(average weight of pulp/average weight of fruit) $\times 100$ ].

\subsection{Chemical analysis}

The parameters analysed included moisture, protein, lipid and ash contents. All analyses were carried out in the feed analysis laboratory of the Animal Sciences Department at 
Table I.

Climatic and soil characteristics of agro-ecological zones of Cameroon where Dacryodes edulis and Canarium schweinfurthii grow $[8,9]$.

\begin{tabular}{|c|c|c|c|c|}
\hline Collection site & Agro-ecological zone & Climate & Relief & Soil type \\
\hline Kekem & Humid forest zone & $\begin{array}{c}\text { Equatorial } \\
\text { Annual rainfall average: } 2300 \mathrm{~mm} \\
\text { Annual temperature average: } 25.5^{\circ} \mathrm{C}\end{array}$ & $\begin{array}{l}\text { Altitude: } 540 \mathrm{~m} \\
\text { Vegetation: } \\
\text { evergreen humid } \\
\quad \text { forest }\end{array}$ & $\begin{array}{c}\text { Ferralitic soils, } \\
\text { rich in organic matter, } \\
\text { average agricultural activities }\end{array}$ \\
\hline Makenene & $\begin{array}{l}\text { Semi-humid forest } \\
\text { zone }\end{array}$ & $\begin{array}{l}\text { Equatorial of the Guinea type } \\
\text { Annual rainfall average: } 2000 \mathrm{~mm} \\
\text { Annual temperature average: } 24.5^{\circ} \mathrm{C}\end{array}$ & $\begin{array}{l}\text { Altitude: } 700 \mathrm{~m} \\
\text { Vegetation: } \\
\text { semi-forest } \\
\text { (transitional) }\end{array}$ & $\begin{array}{c}\text { Ferralitic soils, } \\
\text { average fertility, } \\
\text { average agricultural activities }\end{array}$ \\
\hline Dschang & Grassland zone & $\begin{array}{l}\text { Sub-equatorial of the Cameroon } \\
\text { mountain type } \\
\text { Annual rainfall average: } 1800 \mathrm{~mm} \\
\text { Annual temperature average: } 20^{\circ} \mathrm{C}\end{array}$ & $\begin{array}{l}\text { Altitude: } 800 \mathrm{~m} \\
\text { Vegetation: } \\
\text { Sudan savanna }\end{array}$ & $\begin{array}{c}\text { Ferralitic soils, } \\
\text { average fertility, } \\
\text { intensive agricultural activities }\end{array}$ \\
\hline
\end{tabular}

the University of Dschang (Cameroon) following procedures already published [13]; they were as follows:

- the protein content was estimated by the Kjeldahl method using a micro-Kjeldahl unit;

- the lipid content was measured by the Soxhlet extraction method using petroleum ether;

- the moisture content was obtained by drying the grated pulp in a hot air oven at $105^{\circ} \mathrm{C}$ until a constant weight was attained;

- the ash content was assessed by incinerating dried samples in a muffle furnace at $550{ }^{\circ} \mathrm{C}$ for $4 \mathrm{~h}$.

Samples used for protein and lipid analyses were previously dried at $60^{\circ} \mathrm{C}$ for $24 \mathrm{~h}$. All samples were run in duplicate during analysis.

\subsection{Data analysis}

Data collected on the physical and chemical properties for both fruit types were subjected to an analysis of variance and significant means separated using Duncan's multiple range test [14]. Regression equations were used to investigate any possible correlations between fruit weight and pulp weight for each fruit type in the three agroecological zones.

\section{Results and discussion}

\subsection{Physical and chemical properties of the African pear}

The heaviest fruits originated from Kekem in the humid forest zone while the smallest fruits came from Dschang in the grassland zone (table II). The greatest variation between whole fruits from the same collection site was observed in Kekem, since it had the highest value of standard error. In fact, the weight of the fruits from this site ranged from (76.29 to 145.35$) \mathrm{g}$, with the largest fruit weighing almost twice as much as the smallest one. In an earlier study [12], the fruit length reported $(7.2 \mathrm{~cm})$ was similar to that obtained in Makenene. In general, the fruits from Kekem tended to be most varied in all the properties assessed, as portrayed in the standard deviation values. Pulp thickness was greatest in fruits from Kekem, which was more than twice the thickness of fruits from Dschang. Such results are similar to those reported $(0.45 \mathrm{~cm})$ by other authors [12]. Data analysis revealed that, for each physical characteristic evaluated, the mean differences between collection sites were highly significant $(P<0.001)$ when compared with each other. In addition, the percentage pulp per fruit was highest in Kekem and lowest in Dschang; these data were 


\section{Table II.}

Physical properties of the African pear from different agro-ecological zones of Cameroon where Dacryodes edulis grows $(n=60)$.

\begin{tabular}{|c|c|c|c|c|c|c|}
\hline $\begin{array}{l}\text { Collection } \\
\text { site }\end{array}$ & $\begin{array}{l}\text { Length of fruit } \\
\qquad(\mathrm{cm})\end{array}$ & $\begin{array}{l}\text { Circumference of fruit } \\
\qquad(\mathrm{cm})\end{array}$ & $\begin{array}{l}\text { Thickness of pulp } \\
\text { (cm) }\end{array}$ & $\begin{array}{l}\text { Weight of whole fruit } \\
\text { (g) }\end{array}$ & $\begin{array}{l}\text { Weight of pulp } \\
\text { (g) }\end{array}$ & $\begin{array}{l}\text { Pulp per fruit } \\
\text { (\%) }\end{array}$ \\
\hline Kekem & $8.17 \pm 0.25 a$ & $13.16 \pm 0.39 a$ & $0.90 \pm 0.02 a$ & $95.82 \pm 3.09 a$ & $65.71 \pm 1.58 a$ & 68.58 \\
\hline Makenene & $7.83 \pm 0.06 b$ & $10.88 \pm 0.15 b$ & $0.78 \pm 0.01 b$ & $84.92 \pm 1.73 b$ & $54.74 \pm 0.62 b$ & 64.46 \\
\hline Dschang & $5.52 \pm 0.09 c$ & $8.27 \pm 0.02 c$ & $0.44 \pm 0.01 c$ & $53.28 \pm 1.31 c$ & $31.18 \pm 0.50 \mathrm{c}$ & 58.52 \\
\hline
\end{tabular}

Means ( \pm standard error) with different letters within the same column differ significantly $(P<0.001)$.

\begin{tabular}{|c|c|c|c|c|}
\hline Collection site & $\begin{array}{l}\text { Moisture content } \\
\text { (\%) }\end{array}$ & $\begin{array}{l}\text { Crude proteins } \\
\text { (\% dry matter) }\end{array}$ & $\begin{array}{l}\text { Lipids } \\
\text { (\% dry matter) }\end{array}$ & $\begin{array}{c}\text { Ashes } \\
\text { (\% dry matter) }\end{array}$ \\
\hline Kekem & $59.24 \pm 3.04 \mathrm{a}$ & $8.28 \pm 0.25 a$ & $40.43 \pm 1.42 \mathrm{a}$ & $4.23 \pm 0.17 \mathrm{a}$ \\
\hline Makenene & $53.17 \pm 3.01 \mathrm{a}$ & $7.80 \pm 0.49 a$ & $41.97 \pm 1.85 \mathrm{a}$ & $4.67 \pm 0.26 a$ \\
\hline Dschang & $68.00 \pm 2.23 b$ & $7.28 \pm 0.36 a$ & $32.98 \pm 2.44 b$ & $3.88 \pm 0.30 a$ \\
\hline
\end{tabular}

lower than that (78.7\%) reported in earlier studies [12]. This implies that, although the fruit weight was larger in the present studies, the seed size was also larger.

From the chemical analysis (table III), the moisture content in the African pear was found to be highest in fruits from Dschang and lowest in fruits from Makenene. The moisture content of the fruit in Congo (70.8\%) was similar to that obtained in Dschang [15]. Statistically, there was no significant difference $(P>0.05)$ in moisture content between fruits from Kekem and those from Makenene. Although the percentage of crude protein was highest in fruits from Kekem and lowest in fruits from Dschang, this difference was not significant. A higher protein value (10.2\%). was reported from fruits in Congo [15]. Lipid content was highest in fruits from Makenene but not significantly higher than those from Kekem, although these data were significantly higher $(P<0.05)$ than that found in fruits from Dschang. The lipid content was reported to be $48.4 \%$ in fruits from Congo and $31.9 \%$ in fruits from Nigeria [15]. No significant difference was found in the ash content of the fruits from different collection sites. The ash contents obtained in this study were similar to that reported for fruits from Congo (4.6\%) but very low when compared with that from Nigeria (10.8\%) [15]. These differences could be due to differences in the methods of analysis employed [15] and also as a result of agro-ecological (especially edaphic) differences between zones. No significant correlations were found between the weight of the fruit and the weight of pulp per fruit (table IV).

\subsection{Physical and chemical properties of the Black olive}

Except for the fruit circumference, Black olives from Makenene had superior physical properties to those from Kekem and Dschang, respectively (table $\mathrm{V}$ ). For each parameter 
evaluated, there were highly significant differences between the means in the various collection sites. The heaviest fruits were found in Makenene and the smallest from Dschang. The differences in pulp weight were highly significant between collection sites, with the highest weight recorded in fruits from Makenene and the least in fruits from Dschang. The overall pulp yield per fruit was highest in Kekem and lowest in Dschang. The only significant correlation $(r=0.25)$ that was established between fruit weight and pulp weight was for fruits in Kekem (table IV).

The moisture content was highest in the Black olives from Dschang (table $V I$ ) and significantly different from the fruits of Kekem and those from Makenene, respectively. Crude protein content was not significantly different between fruits from different sites. The lipid content was highest in fruits from Makenene but not significantly different from that in fruits from Kekem. However, the fruits from Dschang were significantly much lower in lipid content than

\section{Table IV.}

Correlation between fruit weight and pulp weight for fruits of Dacryodes edulis (African pears) and Canarium schweinfurthii (Black olives) collected in different sites of Cameroon.

\begin{tabular}{lcc}
\hline Fruit type & Collection site & Correlation coefficient $(r)$ \\
\hline African pear & Kekem & 0.14 \\
$(n=60)$ & Makenene & 0.022 \\
& Dschang & 0.066 \\
Black olive & Kekem & 0.25 \\
$(n=75)$ & Makenene & 0.055 \\
& Dschang & 0.055
\end{tabular}

\section{Table V. \\ Physical properties of the Black olive from different agro-ecological zones of Cameroon where Canarium schweinfurthii grows $(n=75)$.

\begin{tabular}{lccccccc}
$\begin{array}{l}\text { Collection } \\
\text { site }\end{array}$ & $\begin{array}{c}\text { Length of } \\
\text { fruit } \\
(\mathrm{cm})\end{array}$ & $\begin{array}{c}\text { Circumference } \\
\text { of fruit } \\
(\mathrm{cm})\end{array}$ & $\begin{array}{c}\text { Thickness of } \\
\text { pulp } \\
(\mathrm{cm})\end{array}$ & $\begin{array}{c}\text { Weight of whole } \\
\text { fruit } \\
(\mathrm{g})\end{array}$ & $\begin{array}{c}\text { Weight of } \\
\text { pulp } \\
(\mathrm{g})\end{array}$ & $\begin{array}{c}\text { Pulp per } \\
\text { fruit } \\
(\%)\end{array}$ \\
\hline Kekem & $3.10 \pm 0.02 \mathrm{a}$ & $6.13 \pm 0.02 \mathrm{a}$ & $0.43 \pm 0.01 \mathrm{a}$ & $7.15 \pm 0.11 \mathrm{a}$ & $4.08 \pm 0.09 \mathrm{a}$ & 57.06 \\
Makenene & $3.20 \pm 0.02 \mathrm{~b}$ & $6.01 \pm 0.02 \mathrm{~b}$ & $0.51 \pm 0.01 \mathrm{~b}$ & $7.67 \pm 0.17 \mathrm{~b}$ & $4.34 \pm 0.09 \mathrm{~b}$ & 56.58 \\
Dschang & $2.85 \pm 0.02 \mathrm{c}$ & $5.56 \pm 0.02 \mathrm{c}$ & $0.37 \pm 0.01 \mathrm{c}$ & $6.18 \pm 0.17 \mathrm{c}$ & $3.32 \pm 0.09 \mathrm{c}$ & 53.72 \\
\hline
\end{tabular}

Means ( \pm standard error) with different letters within the same column differ significantly $(P<0.001)$.

\section{Table VI.}

Nutrient composition of the Black olive (pulp) from different agro-ecological zones of Cameroon where Canarium schweinfurthii grows $(n=6)$.

\begin{tabular}{lcccc} 
Collection site & $\begin{array}{c}\text { Moisture content } \\
(\%)\end{array}$ & $\begin{array}{c}\text { Crude protein } \\
\text { (\% dry matter) }\end{array}$ & $\begin{array}{c}\text { Lipid } \\
\text { (\% dry matter) }\end{array}$ & $\begin{array}{c}\text { Ash } \\
\text { (\% dry matter) }\end{array}$ \\
\hline Kekem & $45.57 \pm 1.67 \mathrm{a}$ & $7.27 \pm 0.42 \mathrm{a}$ & $53.23 \pm 1.67 \mathrm{a}$ & $5.23 \pm 0.26 \mathrm{a}$ \\
Makenene & $43.28 \pm 1.03 \mathrm{a}$ & $6.98 \pm 0.36 \mathrm{a}$ & $58.00 \pm 1.37 \mathrm{a}$ & $5.87 \pm 0.17 \mathrm{~b}$ \\
Dschang & $51.58 \pm 1.56 \mathrm{~b}$ & $6.47 \pm 0.24 \mathrm{a}$ & $40.53 \pm 1.89 \mathrm{~b}$ & $4.60 \pm 0.20 \mathrm{c}$ \\
Significance & Significant & Non-significant & Highly significant & Significant \\
\hline \multicolumn{2}{l}{ Means ( \pm standard error) with different letters within the same column differ significantly. }
\end{tabular}


those from Kekem and Makenene, respectively. Significant differences were observed in the ash content of the fruits: the highest was found in Makenene and the lowest in Dschang.

\section{Conclusion and recommendations}

Our results reveal great variations in physical properties of the African pear within each zone as well as when it is grown in different agro-ecological zones. Variations in physical properties within each collection site were not as pronounced in the Black olive as in the African pear, indicating that the African pear tree is more heterozygous. Variations in both chemical and physical characteristics were indeed tremendous. For the same agro-ecological zone, such variations could be as a result of differences in the maturity level of the fruits since collection was progressive, and also as a result of the genetic diversity of the trees. Variations between agro-ecological zones could be due to the influential role played by physical factors (such as soil, climate, farming system, etc.) on fruit quality.

Although the African pear was impressive in weight, the pulp yield was not so high, as a result of the large seed size. The same observation was made for the Black olives, whose overall \% pulp yield was even smaller than that of the African pear. Protein and lipid contents in both fruits were not significantly different in the humid and semihumid zones. Since most fruit chemical properties were not significantly different between the Kekem and Makenene collections but higher than in the Dschang one, and since the $\%$ pulp produced per fruit was highest in the Kekem fruits, the humid forest zone in Cameroon would appear to offer the best agro-ecological conditions for the production of the African pear and the Black olive.

In addition, we recommend that a larger sample size be collected each time in order to reduce variations as a result of differences in the degree of maturity of the fruits. It would also be interesting to analyse these physico-chemical properties in fruits from the same trees during fructification. This will give a better indication of the evolution of each property throughout the production season.

\section{References}

[1] Kengue J., Le safoutier, premières données sur la morphologie et la biologie d'une burseracées fruitière et oléifère d'origine africaine, Univ. Yaoundé 1, thèse, Yaoundé, Cameroun, 1990,154 p.

[2] Mapongmetsem P.M., Phénologie et mode de propagation de quelques essences locales à potentiel agroforestier, Univ. Yaoundé 1, thèse, Yaoundé, Cameroun, 1994, 180 p.

[3] Ndoye O., Mannuel R.P., Eyebe A., The markets of non-timber forest products in the humid forest zone of Cameroon, ODI Rural Development Services, Yaounde, Cameroon, 1997.

[4] Okafor J.C., Varietal delimitation in Dacryodes edulis (G. Don) H.J. Lam (Burseraceae) Int. Tree Crops J. 2 (3-4) (1983) 255-265.

[5] Ndangang V.H., A survey of traditional agroforestry woody plants of the North-West province of Cameroon. Pre-optional study report, Natl. Adv. Sch. Agric., Yaounde, Cameroon, 1989, 72 p.

[6] Kengue J., Nya Ngatchou J., Problème de conservation du pouvoir germinatif chez les graines de safoutier (Dacryodes edulis), Fruits 45 (4) (1990) 409-412.

[7] Tailfer Y., La forêt dense d'Afrique centrale. Identification pratique des principaux arbres, Tome II, ACCT, Paris, France,1990.

[8] Neba S.A., Modern geography of the Republic of Cameroon, 2nd ed., Camden, N.J., Neba Publishers, USA, 1987.

[9] Segalen P., Martin D., Les sols du Cameroun oriental, ORSTOM, Paris, France, 1963.

[10] Vivien J., Faure J.J., Fruitiers sauvages d'Afrique. Espèces du Cameroun, Éditions Nguila-Kerou, Clohars Carnoet, France, 1996.

[11] Youmbi E., Étude histologique, cytochimique de la graine, culture in vitro du safoutier, Univ. Paris VIII, thèse, Paris, France, 1991, $132 \mathrm{p}$.

[12] Kapseu C., Tcheingang, C. Contribution à la détermination de la composition de l'huile de deux types de safou, in: Kengue I., Nya 
Ngatchou J. (Eds.), Le safoutier, Actes du séminaire régional sur la valorisation $\mathrm{du}$ safoutier, Douala, Cameroun, 1991.

[13] Anon., Official methods of analysis of the Association of Official Analytical Chemists, 14th ed., AOAC, Washington D.C., USA, 1975.

[14] Steel R.G.D., Torrie J.H., Principles and procedures of statistics. A biometrical approach, 2nd ed., McGraw Hill Book Co., New York, USA, 1980.

[15] Silou T., Kiakouma S., Brice J., Évaluation de la production et étude de la variabilité morphologique et physico-chimique du safou, Dacryodis edulis, in : Kengue I., Nya Ngatchou J. (Eds.), Le safoutier, Actes du séminaire régional sur la valorisation du safoutier, Douala, Cameroun, 1994.

Propiedades físico-químicas del safou y de la "aceituna negra" producidos en distintas zonas agro-ecológicas de Camerún.

Resumen - Introducción. Dacryodes edulis y Canarium schweinfurthii son dos árboles tropicales de usos múltiples en Camerún que producen para el consumo humano frutos (el safou y la aceituna negra, respectivamente) que se comercializan cada vez más en los mercados nacionales e internacionales. Este estudio pretendió caracterizar estos dos frutos a partir de sus propiedades físicas y químicas. Material y métodos. Los frutos se recogieron en plena temporada de cosechas en tres zonas agro-ecológicas de Camerún. Las propiedades físicas medidas fueron el peso, la longitud, la circunferencia del fruto y el grosor de la pulpa, mientras que los análisis químicos se refirieron a los tipos de humedad, proteínas, lípidos y cenizas. Resultados. Los frutos procedentes de bosque húmedo fueron los más grandes (96 g) mientras que los más pequeños procedían de la sabana $(54 \mathrm{~g})$. El rendimiento de la pulpa del fruto más elevado (69\% para el safou y 57\% para la aceituna negra) se registró en los frutos recogidos en bosque húmedo. La correlación más fuerte $(r=0,25)$ entre el peso del fruto y el de la pulpa se observó para la aceituna negra producida en zona forestal húmeda. El porcentaje de proteína bruta fue más elevado (8\%) en los frutos de bosque húmedo mientras que el de los lípidos (42\%) prevaleció en zona semi forestal. Conclusión. La zona de bosque húmeda ofrece mejores condiciones agro-ecológicas para una producción comercial de los frutos de D. edulis y de C. schweinfurthii. Estos dos frutos contienen proteínas y lípidos en cantidades significativas y pueden, por lo tanto, servir de fuentes auxiliares para estos elementos nutritivos.

Camerún / árboles de uso múltiple / Dacryodes edulis / Canarium schweinfurtbii / frutas / composición aproximada 